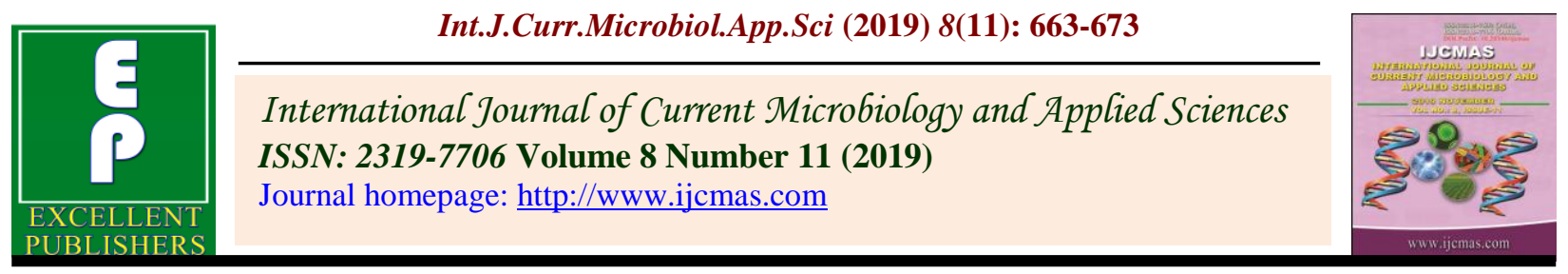

Original Research Article

https://doi.org/10.20546/ijcmas.2019.811.080

\title{
Varietal Comparison of Mango Production and its Efficiency in Karnataka, India
}

\author{
Mukund $^{1}$, B.S. Reddy ${ }^{2 *}$, S.B. Goudappa ${ }^{3}$ and G.M. Hiremath ${ }^{1}$ \\ ${ }^{1}$ Department of Agricultural Economics, UAS, Raichur, 584104, India \\ ${ }^{2}$ Department of Agricultural Economics, College of Agriculture, Kalaburagi, 585101, India \\ ${ }^{3}$ Department of Agricultural Extension Education, UAS, Raichur, 584104, India \\ *Corresponding author
}

\section{Keywords}

Cost of cultivation cost of production, Mango, Variable cost, Variety

Article Info

Accepted:

07 October 2019

Available Online:

10 November 2019

\section{A B S T R A C T}

Mango is the most important commercially grown fruit crop. India is the largest producer and exporter of mango in the world and Karnataka is one of the important mango producing state. The majority of the farmers $(38.33 \%)$ were in the category of annual income of ₹2.01 to ₹3.00 lakh. The extent of use of all the inputs in the cultivation of mango was higher in Alphonso variety compared to Dassehari, Kesar and Bennishan varieties. Consequently, the per acre total cost of cultivation was also higher in Alphonso (₹53.532) compared to Kesar (₹49,794), Dassehari (₹48,549) and Bennishan (₹47,871) varieties. The cost incurred on FYM and fertilizer was the other major cost components of the total variable cost. The per quintal cost of production of Alphonso variety of mango was (₹3,194) and Kesar (₹3013) varieties was higher than that of Dassehari $(₹ 2,948)$ and Bennishan $(₹ 2,919)$ varieties. However, the magnitude of benefit-cost ratio was higher in Alphonso (2.08) followed by Dassehari (2.00), Kesar (1.87) and Bennishan (1.48) with average ratio of 1.86 across the varieties mainly because of higher price fetched and lower cost incurred especially on Alphonso variety.

\section{Introduction}

Mango (Mangifera indica L.) belonging to family Anacardiaceae is the most important commercially grown fruit crop. Among the major fruits produced in the world, mango contributes 46.50 million tonnes of production. India is the largest producer and exporter of mango in the world. Mango is a important tropical fruit and it is grown in almost all the countries in the world. The major mango producing countries in the world are India (42.02\%), China (10.69\%), Thailand $(7.69 \%)$, Mexico (4.92\%) and Indonesia (4.89 $\%)$. The area under mango cultivation in India was 22.67 lakh hectares with the production of around 202.95 lakh tonnes, accounting 42.02 per cent of the total world production. The 
major mango producing states are Uttar Pradesh (23.06\%), Andhra Pradesh (16.07\%), Karnataka $(9.29 \%)$, Bihar $(7.52 \%)$, Gujarat $(6.31 \%)$ and Tamil Nadu (5.88\%).

The area and production of mango in Karnataka was 1.44 lakh hectares and 7.58 lakh tonnes during 2014-15 respectively. The Mango fruit is cultivated in almost all the districts of Karnataka. Among the districts, Kolar contributed highest production of 1.50 lakh tonnes followed by Ramnagar district (1.02 lakh tonnes) during 2014-15. Among the districts of Karnataka, districts of NEK region contribute 4.71 per cent to mango production in the state. The area under mango cultivation in the region was 5.40 lakh hectares with the production of 35,688 tonnes (Anon, 2015).

Alphonso, Benishaan or Benisha (Banganapalli in Telugu and Tamil) and Kesar mango varieties are considered among the best mangoes in southern states of India, while Dussehri and Laungra varieties are most popular in the northern states. The fruit is very popular with the masses due to its wide range of adaptability, high nutritive value and richness in variety, delicious taste and excellent flavour. It is a rich source of vitamin $\mathrm{A}$ and $\mathrm{C}$. The fruit is consumed raw or ripe. Good mango varieties contain 20 per cent of total soluble sugars. The acid content of ripe desert fruit varies from 0.2 to 0.5 per cent and protein content is about one per cent.

Raw fruits of local varieties of mango are used for preparing various traditional products like raw slices in brine, amchur, pickle, murabba, chutney, panhe (sharabat), etc. Presently, the raw fruit of local varieties of mango are used for preparing pickle and Alphonso variety is used for squash in coastal western zone.

High investment is required for establishing a mango orchard. The cost of establishing a mango orchard up to bearing includes not only the cost incurred in the initial year that is at the time of planting but also the cost incurred in maintaining the plants up to its lifespan.

The cost incurred on construction of Kaccha house, planting material, digging and filling of pits were the major component of the establishment cost. Similarly, risk of profitability is also high in mango farming. The farmers are attracted towards mango farming. Since nutrients are prone to heavy losses in soils, farmers in study area practiced application of high manures and fertilizer doses.

In view of this, there is good scope for making comprehensive study on investment in mango orchard. Keeping this in mind the study was undertaken to analyse the varietal comparision of mango production and its efficiency in Karnataka.

\section{Materials and Methods}

The study was conducted in North-Eastern Karnataka, which constitutes six districts namely Bidar, Kalaburagi, Yadgir, Raichur, Ballari and Koppal. Out of these six districts four districts namely Koppal, Bidar, Kalaburagi and Ballari districts were selected for the study based on the highest area under mango crop. A purposive multi-stage random sampling technique was used to collect the required information from the sample farmers. Further, 15 farmers from selected districts were selected at random in view of spread out of mango growers in different villages of selected district. Totally 60 mango growing farmers were selected for the study.

\section{Distribution of variety}

The Bennishan is the popular variety grown by 14 farmers out of 15 sample respondents in Koppal districts. Similarly, 9 farmers were grown Alphonso variety out of 15 
respondents. Hence, Bennishan and Alphonso varieties were extensively grown in Koppal district.

In case of Bidar district Kesar, Dassehari and Bennishan varieties were popularly grown in the district. Whereas, Bennishan (12 farmers) and Kesar (09 farmers) varieties were cultivated in Kalaburagi district. Similarly, Bennishan (09 farmers) and Alphonso (05 farmers) were the major varieties grown in Ballari district. Therefore Bennishan, Alphonso, Kesar and Dassehari varieties were extensively grown in the study area.

\section{Analytical tools employed}

\section{Tabular analysis}

The data collected were presented in tabular form to facilitate easy comparisons. The Socio-economic features, investment pattern, costs and returns and constraints faced by the producers a were studied using tabular analysis. The data were summarized with the help of statistical tools like averages and percentages to obtain meaningful inferences.

\section{Results and Discussion}

The socio-economic characteristics were studied to know the farmers details about information pertaining to mango production and marketing. The general characteristics of the sample farmers presented in Table 1 revealed that majority of the mango producing farmers $(48.33 \%)$ were between the age group of 41-60 years followed by 20-40 years age group $(35.00 \%)$ and $61-80$ years age group $(16.67 \%)$. It is also clear from the table that on an average farmers involved in mango production were having around 47 years in the study area. It is important to note that majority of the mango producing farmers had college education (76.66\%) followed by high school $(21.67 \%)$ and primary education (1.67\%). It is worth to mention that none of the respondents were illiterate. The findings clearly indicated that educated farmers are taking up mango cultivation and are ready to take risky enterprise. This might be due to profitability of the enterprise and also farmers have been exposed to modern and improved mango cultivation practices. The average family size of the respondents in the study area was six constituting of three men and three women members in the family. On an average the area under mango sample farmers was 2.26 hectare. With respect to land holding, majority of the respondents $(40 \%)$ were small ( $<2 \mathrm{ha})$ followed by medium (33.33\%) and large (26.67\%) size holdings. The results are in line with the study conducted by Ravikumar 2010 . The economic status of mango growing farmers indicated that on an average the mango growing farmers were having annual income of ₹3,28,333. Majority (38.33\%) of the respondents were having an annual income between ₹2,00,001 to ₹3,00,000. About 23.33 per cent of the respondents were having an annual income of above ₹4,00,000, and 15.00 per cent of the respondents were having an annual income between ₹3,00,001 to $₹ 4,00,000$. Further about 13.33 per cent of the respondents were having an annual income of $₹ 1,00,000$ to ₹2,00,000 and only 10.00 per cent of the respondents were having an annual income below ₹ $1,00,000$. This clearly shows that mango growing farmers were have better financial status (Table 2).

\section{Alphonso mango production}

Alphonso variety of mango is the one of the important commercially grown variety of India and it fetches high price compared to all other varieties grown in the country. On an average, farmers incurred a total cost of ₹53,532 per acre, of which variable cost accounted for more than 50 per cent. Among the variable costs, expenditure on human labour $(29.94 \%)$ constituted major item of 
total cost followed by expenditure on farmyard manure (12.51\%) and fertilizer $(4.93 \%)$ this might to due excess dose of inputs needed for cultivation. The rental value of land (14.94\%) formed major component of the total cost of cultivation among fixed costs followed by amortized establishment cost (16.26\%), depreciation cost (6.94\%). On an average, per acre total maintenance cost per annum worked out to be ₹53,532 across the selected districts. The total cost was composition of labour (₹16,027), material (₹13,063) and fixed (₹24,442) costs. The cost of production was worked out to be ₹ 3,194. The per acre average yield obtained by farmers was 20.60 quintals and have realized average price of ₹5,400 per quintal. The overall per acre average net returns obtained by mango growers amounted to ₹57,708 with gross returns of ₹1,11,240. The returns per rupee of investment worked out to be higher (₹2.08) compared to other varieties. This is because higher price fetched by Alphonso variety of mango. Similar study were conducted by Naik (2005) on mango production, processing and export in south Konkan region of Maharastra.

\section{Kesar mango production}

Perusal of Table 3 indicates that, the Kesar variety of mango cultivating farmers incurred a total cost of ₹49,794 per acre, out of which ₹26,185 (52.58\%) were constituted by variable costs. Of the total cost of cultivation, the expenditure on human labour (29.96\%) formed major component followed by farmyard manure $(11.38 \%)$, watch and ward (9.20\%), labour cost on harvesting $(5.41 \%)$ and fertilizers $(4.61 \%)$. The rental value of land formed major (16.07\%) cost among fixed costs followed by amortized establishment
$(15.94 \%)$ cost. The per quintal cost of production was estimated to be ₹3013. The average yield harvested by mango producer was 22.60 quintals and have realized average price of ₹4,200 per quintal. The overall average net returns and gross returns obtained from mango production were worked out to be $₹ 43,446$ and ₹93,240 respectively. The returns per rupee of investment was found to be ₹1.87.

\section{Dassehari mango production}

In case of Dassehari variety of mango (Table $4)$, the per acre overall total cost of cultivation amounted to ₹48,459 of which ₹24,598 $(50.76 \%)$ was incurred on variable costs. Out of the total cost of cultivation, the expenditure on human labour $(31.47 \%)$ formed the major component as was observed in the previous section, followed by cost on watch and ward $(9.45 \%)$. The expenditure on farmyard manure (9.24\%), labour expenditure for harvesting (7.04\%), weeding $(4.71 \%)$ and chemical fertilizers $(3.58 \%)$ were the other important variable costs while amortized establishment cost $(16.86 \%)$ formed major cost among the fixed cost followed by rental value of land $(16.51 \%)$. The per quintal cost of production was worked out to be ₹2,948. In case of returns, the average yield of Dassehari variety mango harvested was 25.10 quintal and the price realized was ₹3,865 per quintal. The gross returns and net returns obtained from Dassehari variety of mango estimated to be ₹97,012 and ₹48,553 respectively. The returns per rupee of investment were estimated to be ₹2.00. Dassehari variety fetches high price hence there is high returns per rupee of investment. Similar results were obtained by Bhat et al., (2011) conducted study on economics of Kinnow production in Himalayan region of Jammu and Kashmir. 
Table.1 Socio-economic features of the sample respondent

\begin{tabular}{|c|c|c|c|}
\hline SI.No & Particulars & Frequency & Percent \\
\hline \multirow[t]{6}{*}{1} & Age (Years) & & \\
\hline & $<40$ & 21 & 35.00 \\
\hline & 40 to 60 & 29 & 48.33 \\
\hline & $>60-80$ & 10 & 16.67 \\
\hline & Average age & 47 & - \\
\hline & Total & 60 & 100.00 \\
\hline \multirow[t]{6}{*}{2} & Education level & & \\
\hline & Illiterate & 00 & 0.00 \\
\hline & Primary school & 01 & 1.67 \\
\hline & High school & 13 & 21.67 \\
\hline & College and above & 46 & 76.66 \\
\hline & Total & 60 & 100.00 \\
\hline \multirow[t]{4}{*}{3} & Average family size (No.) & & \\
\hline & Male & 03 & 50.00 \\
\hline & Female & 03 & 50.00 \\
\hline & Total & 06 & 100.00 \\
\hline 4 & Average area under mango (ha) & 2.26 & \\
\hline \multirow[t]{5}{*}{5} & Land holding size (No.) & & \\
\hline & Small (<2 ha) & 24 & 40.00 \\
\hline & Medium (2-4 ha) & 20 & 33.33 \\
\hline & Large (>4 ha) & 16 & 26.67 \\
\hline & Total & 60 & 100.00 \\
\hline \multirow[t]{8}{*}{6} & Economic status of mango growers & & \\
\hline & $<1$ lakh & 06 & 10.00 \\
\hline & 1.00- 2.00 lakh & 08 & 13.33 \\
\hline & 2.01-3.00 lakh & 23 & 38.33 \\
\hline & 3.01-4.00 lakh & 09 & 15.00 \\
\hline & $>4.01$ lakh & 14 & 23.33 \\
\hline & Total & 60 & 100.00 \\
\hline & Average annual income (₹) & \multicolumn{2}{|c|}{$3,28,333 /-$} \\
\hline
\end{tabular}


Table.2 Costs and returns of Alphonso mango production

\begin{tabular}{|c|c|c|c|c|}
\hline Sl.No & Particulars & Quantity & Value (₹) & \% Share \\
\hline I & Labour cost (Mandays) & & & \\
\hline 1 & Application of FYM and fertilizer & 8.40 & 2310 & 4.32 \\
\hline 2 & Application of PP chemicals & 4.50 & 1237 & 2.31 \\
\hline 3 & Watch and ward & 1.00 & 4580 & 8.56 \\
\hline 4 & Weeding & 9.30 & 2557 & 4.78 \\
\hline 5 & Irrigation & 3.70 & 1018 & 1.90 \\
\hline 6 & Harvesting & 11.52 & 3170 & 5.92 \\
\hline \multirow[t]{2}{*}{7} & Miscellaneous & 4.20 & 1155 & 2.16 \\
\hline & Sub-total & & 16027 & 29.94 \\
\hline II & Material cost & & & \\
\hline 8 & FYM (tonnes) & 1.30 & 6695 & 12.51 \\
\hline 9 & Fertilizer & & & 0.00 \\
\hline $\mathbf{a}$ & Urea $(\mathrm{kg})$ & 22.50 & 247 & 0.46 \\
\hline b & $\mathrm{DAP}(\mathrm{kg})$ & 52.00 & 2392 & 4.47 \\
\hline 10 & PPC (ltrs) & 1.50 & 890 & 1.66 \\
\hline 11 & Growth regulators $(\mathrm{kg})$ & 1.20 & 936 & 1.75 \\
\hline \multirow[t]{2}{*}{12} & Interest on working capital@ 7 per cent & & 1903 & 3.55 \\
\hline & Sub-total & & 13063 & 24.40 \\
\hline III & Fixed cost & & & \\
\hline 13 & Rental value of land & & 8000 & 14.94 \\
\hline 14 & Land revenue & & 257 & 0.48 \\
\hline 15 & Amortized establishment cost & & 8703 & 16.26 \\
\hline 16 & Depreciation & & 3713 & 6.94 \\
\hline 17 & Irrigation structure & & 1751 & 3.27 \\
\hline \multirow[t]{3}{*}{18} & Interest on fixed cost@9 per cent & & 2018 & 3.77 \\
\hline & Sub-total & & 24442 & 45.66 \\
\hline & Total cost $(I+I I+I I I)$ & & 53532 & 100.00 \\
\hline IV & Returns & & & \\
\hline $\mathbf{a}$ & Yield (q) & 20.60 & - & - \\
\hline b & Price realized (₹/q) & & 5400 & - \\
\hline c & Cost of production (₹/q) & & 3194 & - \\
\hline d & Gross returns $(₹)$ & & 111240 & - \\
\hline e & Net returns $(₹)$ & & 57708 & - \\
\hline d & Returns per rupee of investment & & 2.08 & - \\
\hline
\end{tabular}

Note: Decimal values are rounded to its nearest value 
Table.3 Costs and returns of Kesar mango production

\begin{tabular}{|c|c|c|c|c|}
\hline & & & & (₹/acre) \\
\hline Sl.No & Particulars & Quantity & Value (₹) & \% Share \\
\hline I & Labour cost (Mandays) & & & \\
\hline 1 & Application of FYM and fertilizer & 7.80 & 2145 & 4.31 \\
\hline 2 & Application of PP chemicals & 4.30 & 1183 & 2.38 \\
\hline 3 & Watch and ward & 1.00 & 4580 & 9.20 \\
\hline 4 & Weeding & 8.30 & 2283 & 4.58 \\
\hline 5 & Irrigation & 3.20 & 880 & 1.77 \\
\hline 6 & Harvesting & 9.80 & 2695 & 5.41 \\
\hline \multirow[t]{2}{*}{7} & Miscellaneous & 4.20 & 1155 & 2.32 \\
\hline & Sub-total & & 14920 & 29.96 \\
\hline II & Material cost & & & \\
\hline 8 & FYM (tonnes) & 1.10 & 5665 & 11.38 \\
\hline 9 & Fertilizer & & & \\
\hline $\mathbf{a}$ & Urea $(\mathrm{kg})$ & 20.50 & 225 & 0.45 \\
\hline b & $\mathrm{DAP}(\mathrm{kg})$ & 45.00 & 2070 & 4.16 \\
\hline 10 & PPC (ltrs) & 1.20 & 890 & 1.79 \\
\hline 11 & Growth regulators $(\mathrm{kg})$ & 0.90 & 702 & 1.41 \\
\hline \multirow[t]{2}{*}{12} & $\begin{array}{c}\text { Interest on working capital @ } 7 \text { per } \\
\text { cent }\end{array}$ & & 1713 & 3.44 \\
\hline & Sub-total & & 11265 & 22.62 \\
\hline III & Fixed cost & & & \\
\hline 13 & Rental value of land & & 8000 & 16.07 \\
\hline 14 & Land revenue & & 257 & 0.52 \\
\hline 15 & Amortized establishment cost & & 7939 & 15.94 \\
\hline 16 & Depreciation & & 3713 & 7.46 \\
\hline 17 & Irrigation structure & & 1751 & 3.52 \\
\hline \multirow[t]{3}{*}{18} & Interest on fixed cost @9 per cent & & 1949 & 3.91 \\
\hline & Sub-total & & 23609 & 47.41 \\
\hline & Total cost $(\mathrm{I}+\mathrm{II}+\mathrm{III})$ & & 49794 & 100.00 \\
\hline IV & Returns & & & \\
\hline $\mathbf{a}$ & Yield (q) & 22.20 & - & - \\
\hline b & Price realized (₹/q) & & 4200 & - \\
\hline c & Cost of production (₹/q) & & 3013 & - \\
\hline d & Gross returns (₹) & & 93240 & - \\
\hline e & Net returns $(₹)$ & & 43446 & - \\
\hline f & Returns per rupee of investment & & 1.87 & - \\
\hline
\end{tabular}

Note: Decimal values are rounded to its nearest value 
Table.4 Costs and returns of Dassehari mango production

\begin{tabular}{|c|c|c|c|c|}
\hline Sl.No & Particulars & Quantity & Value (₹) & \% Share \\
\hline I & Labour cost (Mandays) & & & \\
\hline 1 & Application of FYM and fertilizer & 7.40 & 2035 & 4.20 \\
\hline 2 & Application of PP chemicals & 3.70 & 1018 & 2.10 \\
\hline 3 & Watch and ward & 1.00 & 4580 & 9.45 \\
\hline 4 & Weeding & 8.30 & 2282 & 4.71 \\
\hline 5 & Irrigation & 3.80 & 1045 & 2.16 \\
\hline 6 & Harvesting & 12.40 & 3410 & 7.04 \\
\hline \multirow[t]{2}{*}{7} & Miscellaneous & 3.20 & 880 & 1.82 \\
\hline & Sub-total & & 15250 & 31.47 \\
\hline II & Material cost & & & \\
\hline 8 & FYM (tonnes) & 0.87 & 4480 & 9.24 \\
\hline 9 & Fertilizer & & & \\
\hline $\mathbf{a}$ & Urea (kg) & 15.60 & 172 & 0.35 \\
\hline b & DAP (kg) & 34.00 & 1564 & 3.23 \\
\hline 10 & PPC (1trs) & 0.96 & 853 & 1.76 \\
\hline 11 & Growth regulators $(\mathrm{kg})$ & 1.00 & 670 & 1.38 \\
\hline \multirow[t]{2}{*}{12} & $\begin{array}{c}\text { Interest on working capital @ } 7 \text { per } \\
\text { cent }\end{array}$ & & 1609 & 3.32 \\
\hline & Sub-total & & 9348 & 19.29 \\
\hline III & Fixed cost & & & \\
\hline 13 & Rental value of land & & 8000 & 16.51 \\
\hline 14 & Land revenue & & 257 & 0.53 \\
\hline 15 & Amortized establishment cost & & 8170 & 16.86 \\
\hline 16 & Depreciation & & 3713 & 7.66 \\
\hline 17 & Irrigation structure & & 1751 & 3.61 \\
\hline \multirow[t]{3}{*}{18} & Interest on fixed cost @9 per cent & & 1970 & 4.07 \\
\hline & Sub-total & & 23861 & 49.24 \\
\hline & Total cost $(I+I I+I I I)$ & & 48459 & 100.00 \\
\hline IV & Returns & & & \\
\hline a & Yield (q) & 25.10 & - & - \\
\hline b & Price realized (₹/q) & & 3865 & - \\
\hline c & Cost of production (₹/q) & & 2948 & - \\
\hline d & Gross returns (₹) & & 97012 & - \\
\hline e & Net returns (₹) & & 48553 & - \\
\hline f & Returns per rupee of investment & & 2.00 & - \\
\hline
\end{tabular}

Note: Decimal values are rounded to its nearest value 
Table.5 Costs and returns of Bennishan mango production

\begin{tabular}{|c|c|c|c|c|}
\hline SI.No & Particulars & Ouantity & Value (₹) & $\%$ Share \\
\hline I & Labour cost (Mandays) & & & \\
\hline 1 & Application of FYM and fertilizer & 6.70 & 1843 & 3.85 \\
\hline 2 & Application of PP chemicals & 3.40 & 935 & 1.95 \\
\hline 3 & Watch and ward & 1.00 & 4580 & 9.57 \\
\hline 4 & Weeding & 7.40 & 2035 & 4.25 \\
\hline 5 & Irrigation & 4.66 & 1282 & 2.68 \\
\hline 6 & Harvesting & 8.30 & 2283 & 4.77 \\
\hline \multirow[t]{2}{*}{7} & Miscellaneous & 3.70 & 1018 & 2.13 \\
\hline & Sub-total & & 13977 & 29.20 \\
\hline II & Material cost & & & \\
\hline 8 & FYM (tonnes) & 0.98 & 5047 & 10.54 \\
\hline 9 & Fertilizer & & & 0.00 \\
\hline $\mathbf{a}$ & Urea $(\mathrm{kg})$ & 18.30 & 201 & 0.42 \\
\hline b & DAP $(\mathrm{kg})$ & 41.00 & 1886 & 3.94 \\
\hline 10 & PPC (ltrs) & 1.00 & 889 & 1.86 \\
\hline 11 & Growth regulators $(\mathrm{kg})$ & 1.10 & 670 & 1.40 \\
\hline \multirow[t]{2}{*}{12} & Interest on working capital @7 per cent & & 1587 & 3.32 \\
\hline & Sub-total & & 10280 & 21.47 \\
\hline III & Fixed cost & & & \\
\hline 13 & Rental value of land & & 8000 & 16.71 \\
\hline 14 & Land revenue & & 257 & 0.54 \\
\hline 15 & Amortized establishment cost & & 7943 & 16.59 \\
\hline 16 & Depreciation & & 3713 & 7.76 \\
\hline 17 & Irrigation structure & & 1751 & 3.66 \\
\hline \multirow[t]{3}{*}{18} & Interest on fixed cost @9 per cent & & 1950 & 4.07 \\
\hline & Sub-total & & 23614 & 49.33 \\
\hline & Total cost (I+II+III) & & 47871 & 100.00 \\
\hline IV & Returns & & & \\
\hline $\mathbf{a}$ & Yield (q) & 24.70 & - & - \\
\hline b & Price realized $(₹ / q)$ & & 2860 & - \\
\hline c & Cost of production (₹/q) & & 2919 & - \\
\hline d & Gross returns (₹) & & 70642 & - \\
\hline e & Net returns (₹) & & 22771 & - \\
\hline $\mathbf{f}$ & Returns per rupee of investment & & 1.48 & - \\
\hline
\end{tabular}

Note: Decimal values are rounded to its nearest value 


\section{Bennishan mango production}

A perusal of Table 5 revealed that the pattern of cost structure in Bennishan variety of mango production was similar to that of Dassehari. The overall cost of cultivation was observed to be ₹47,871 per acre, of which ₹24,257 (50.67\%) was incurred as variable costs. Out of the total cost of cultivation, again the expenditure on human labour $(29.20 \%)$ formed the major component followed by cost on farmyard manure (10.54\%) this might be due to less use of fertilizers and other inputs. The expenditure on watch and ward (9.57\%), labour expenditure on harvesting (4.77\%), chemical fertilizers $(4.36 \%)$ and weeding $(4.25 \%)$ were the other important variable costs while rental value of land $(16.71 \%)$ formed major cost component among fixed cost followed by amortized establishment cost (16.59\%). The per quintal cost of production was estimated to be ₹2,919. The per acre average yield obtained by the mango production was 24.70 quintals and have realized a price of ₹2,860 per quintal. The net and gross returns obtained were ₹22,771 and ₹70,642 respectively. The returns per rupee of investment were ₹1.48 rupees which was relatively less when compared to other varieties. Bennishan variety fetches low price hence there is reduced net income and $\mathrm{B}$ : C ratio compared to other varieties in the study.

The study finally concludes that the variable cost incurred by the farmers during establishment of orchard found to be around 48.42 per cent of the total cost. The extent of variable cost in the total establishment cost varies across the varieties. The extent of use of all the inputs in the cultivation of mango was higher in Alphonso variety compared to Dassehari, Kesar and Bennishan varieties. Consequently, the per acre total cost of cultivation was also higher in Alphonso (₹53.532) compared to Kesar (₹49,794), Dassehari (₹48,549) and Bennishan (₹47,871) varieties. The variable cost incurred by the farmers was found to be more than 45 per cent of the total cost of cultivation of mango. However, expenditure on human labour (30.14\%) was the major constituent of total variable cost in all the varieties. The per quintal cost of production of Alphonso variety of mango was $(₹ 3,194)$ and Kesar (₹3013) varieties was higher than that of Dassehari $(₹ 2,948)$ and Bennishan (₹2,919) varieties. This phenomenon calls for educating mango producer for proper as well as judicious use of inputs. Keeping this in view farmers should concentrate on re-allocation of resources and thereafter consider on adoption of new technologies for increasing production and profitability. However, the magnitude of benefit-cost ratio was higher in Alphonso (2.08) followed by Dassehari (2.00), Kesar (1.87) and Bennishan (1.48) with average ratio of 1.86 across the varieties mainly because of higher price fetched and lower cost incurred especially on Alphonso variety.

\section{References}

Annonymous, 2015. Karnataka at a glance published by Directorates of Economics and Statistics, Bangalore. pp-154.

Bhat, A., Kachroo, J. and Kachroo, D., 2011. Economic appraisal of kinnow production and its marketing under North-Western Himalayan region of Jammu. Agricultural Economic Research Review, 24(2): 283-290.

Naik, V. G., 2005. An economic analysis of mango production, processing and export in South Konkan region of Maharashtra. Ph.D. Thesis, Univ. Agric. Sci., Dapoli.

Ravikumar, C. M., 2010. Supply chain management of mango processing- A case study of Kolar districts, MBA Thesis, Univ. Agric. Sci., Bengaluru, Karnataka (India). 
How to cite this article:

Mukund, B.S. Reddy, S.B. Goudappa and Hiremath, G.M. 2019. Varietal Comparison of Mango Production and its Efficiency in Karnataka. Int.J.Curr.Microbiol.App.Sci. 8(11): 663673. doi: https://doi.org/10.20546/ijcmas.2019.811.080 